\title{
RURAL ALABAMA SMALL BUSINESS OWNERS
}

\section{Agree Alabama Should Help Workers Save For the Future}
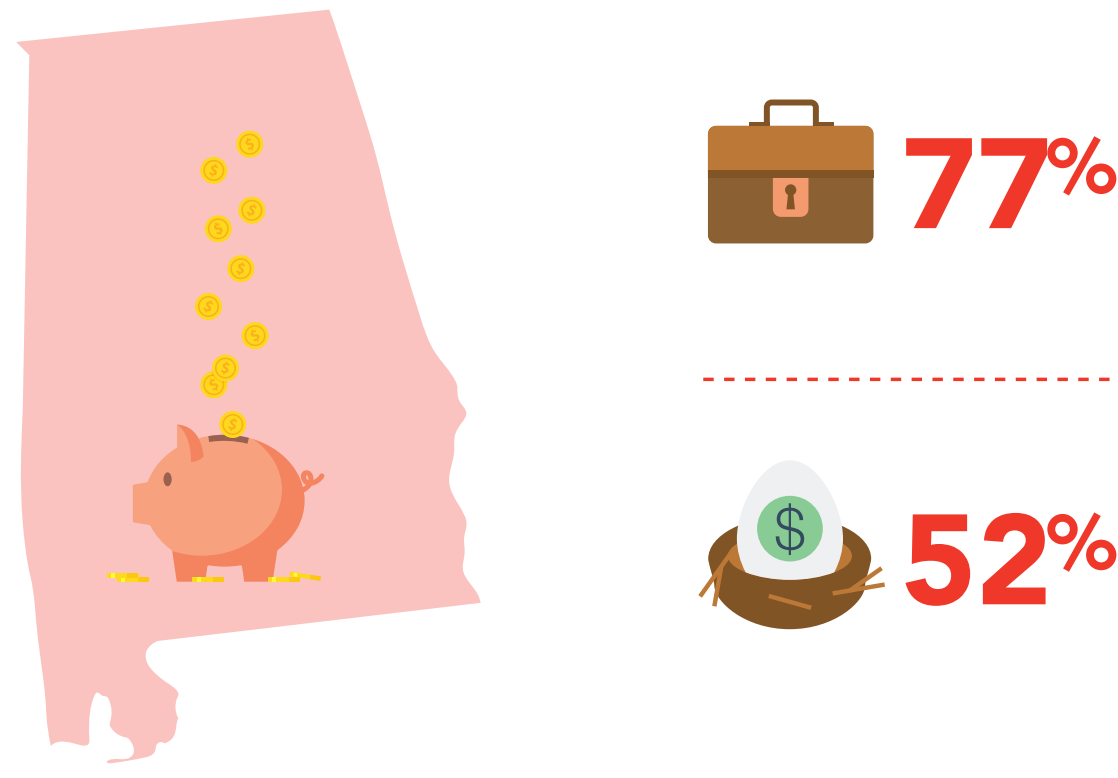

agree that the state should

do more to encourage residents to save for retirement.

\section{Support a State Retirement Savings Option} ready-to-go Alabama retirement savings option.

express concern about themselves and their employees having enough money to cover health care or living expenses in retirement. 